\title{
EFFECT OF SOWING TIME BASED TEMPERATURE VARIATIONS ON GROWTH, YIELD AND SEED QUALITY OF GARDEN PEA
}

\author{
M. Z. Ali ${ }^{1}$, M. A. Aziz ${ }^{1}$, M. A. I. Sarker ${ }^{1}$, S. Mazumder ${ }^{2}$, S. K. Paul ${ }^{\star}$, T. A. Mujahidi ${ }^{3}$ \\ M. S. A. Khan and M. S. Bhuiyan ${ }^{1}$ \\ ${ }^{1}$ Agronomy Division, Bangladesh Agricultural Research Institute, Joydebpur, Gazipur-1701, Bangladesh. \\ ${ }^{2}$ Sher-e-Bangla Nagar Adarsha Mohila College, Dhaka-1207 \\ ${ }^{3}$ Scientific Officer, Plant Breeding Division, Bangladesh Agril. Res. Institute, Joydebpur, Gazipur-1701, Bangladesh \\ *Corresponding Author: santosh87dhaka@gmail.com
}

Key words: Temperature, gardenpea, phenology, growth, yield, seed quality

\begin{abstract}
A field experiment was conducted at the research field of Agronomy Division, BARI, Joydebpur, Gazipur and ARS, Burirhat, Rangpur to evaluate crop growth, yield and seed quality of garden pea in prevailing temperature at different sowing dates (10 November, 20 November, 30 November, 10 December, 20 December and 30 December). Sowing date based temperature variations significantly affected the crop growth, TDM production, yield and seed quality of BARI Motorshuti-3. Plants with November 20-30 sowing performed the best in respect of yield and yield contributing characters. However, with the delayed in sowing dates, the temperatures at the later growth phases were increased, while the grain growth duration, grain yield and grain quality decreased substantially. Results revealed that November 20-30 would be the optimum time of sowing for maximum yield with quality seed production of garden pea in Bangladesh.
\end{abstract}

\section{Introduction}

The garden pea is grown mainly for young pod to get tender green seeds as vegetable. The mature seeds can be used for preparing dal or chatpati. The crop has gained popularity for its short growth duration and high nutritive value. Green pods are rich in vitamins, protein and minerals. Besides, a huge amount of garden pea is consumed as soup. Garden pea can play an important role to over come our national protein deficit. Its demand especially to the urban people is increasing day by day. Garden pea is a cool loving crop. It grows well in winter and partly moist climatic condition. An increase in temperature above $20{ }^{\circ} \mathrm{C}$ decreases the yield and quality of immature seeds. Temperature above $30{ }^{\circ} \mathrm{C}$ is harmful for garden pea (Sousa-Majer et al., 2004). Temperature is an important environmental factor that affects the growth of plants in several ways, from root growth, nutrient uptake, and water absorption from the soil, to photosynthesis, respiration, and translocation of photosynthate. Sowing at proper time allows sufficient growth and development of a crop to obtain a satisfactory yield because high temperature is one of the major environmental stresses that affect plant growth and development (Boyer, 1982). High temperature affects a host of physiological processes, the most relevant of which are respiration, photosynthesis, photosynthate translocation and membrane composition and stability as a result the crop yield decrease (Sing, 2006). It was reported that different environmental conditions, especially temperature due to different sowing time provide variable in crop growth, development and yield stability (Pandey et al., 1981). So, it is necessary to study the crop growth behaviors in changing climatic condition for future requirement. Therefore, the 
Ali et al.

present experiment was conducted to evaluate the crop growth pattern, yield and seed quality under different temperature resulted from different sowing time.

\section{Materials and Methods}

The trial was conducted at the research field of Agronomy Division, BARI, Joydebpur, Gazipur and ARS, Burirhat, Rangpur during rabi season of 2011-2012 to find out the crop growth pattern, yield and seed quality under different temperature resulted from different sowing time. Six sowing dates (10 November, 20 November, 30 November, 10 December, 20 December and 30 December) were evaluated in RCB design with 3 replications. The unit plot size was $3 \mathrm{~m} \times 4 \mathrm{~m}$. Garden pea var. BARI Motorshuti-3 was used in the experiment. Fertilizers @ $\mathrm{N}_{60} \mathrm{P}_{28} \mathrm{~K}_{40} \mathrm{~S}_{12} \mathrm{~kg} / \mathrm{ha}$ were applied in the form of Urea, Triple super phosphate (TSP), Muriate of potash (MoP) and Zinc sulphate, respectively. All fertilizers were applied as basal. Intercultural operations such as weeding, thinning and irrigations were done as and when required. For dry matter estimation and crop growth analysis, 5 plants were sampled at 5 days interval up to maturity. The collected samples were dried component-wise in an oven at $70{ }^{\circ} \mathrm{C}$ for 72 hours. The yield component data was taken from 10 randomly selected plants prior to harvest from each plot. At harvest, the yield data was recorded plot wise. The collected data were analyzed statistically and the means were adjusted following LSD test. Seed protein content was analyzed by Neo infrared analyzer (NIR) (DA 7200 Diode Array Analyzer). Following ISTA (1999) rules seed quality such as moisture (\%) content, seed germination (\%) and vigor index (Abdul-Baki and Anderson, 1973) were recorded by the following formulae:

$\%$ Moisture Content $=\frac{M_{2}+M_{3}}{M_{2}+M_{1}} \times 100$

Where,

$M_{1}=$ Weight in grams of the container and its cover,

$\mathrm{M}_{2}=$ Weight in grams of the container, its cover and garden pea seed before drying, and

$\mathrm{M}_{3}=$ Weight in grams of the container, cover and garden pea seed after drying

Seed germination $(\%)=\frac{\text { No. of seedgerminated }}{\text { Total seedtested }} \times 100$

Vigor index $(\mathrm{VI})=$ Average seedling dry weight $(\mathrm{g}) \times$ seed germination $(\%)$

Leaf area index $(\mathrm{LAI})=\frac{\text { Leaf area }}{\text { Groundarea }}(\mathrm{m} 2 / \mathrm{m} 2)$

\section{Results and Discussion}

Phenology and crop growth duration was influenced by prevailing temperature variations. November 30 sowing took maximum dura++tion for crop growth (84 days) followed by 20 November (83 days) and 10 November ( 81 days) and it was 77, 74 and 70 days for 10 December, 20 December and 30 December sowing, respectively. The reasons for variation in growth duration might be due to variation in day/night temperature and increased in temperature at the later sowing curtailed the crop growth duration (Table 1a and 1b). 
Effect of Sowing Time Based Temperature Variations on Growth, Yield and Seed Quality of Garden

Pea

Table 1a. Crop phenology and growth duration of Gardenpea (BARI motorshuti-3) as affected by sowing dates

\begin{tabular}{l|c|c|c|c|c|c|c}
\hline Sowing dates & $\begin{array}{c}\text { Emer- } \\
\text { gence }\end{array}$ & $\begin{array}{c}\text { Avg. Min. } \\
\text { Tem. }{ }^{0} \mathrm{C} \text { at } \\
\text { emergenc } \\
\text { e stage }\end{array}$ & $\begin{array}{c}\text { Avg. Max. } \\
\text { Tem. }{ }^{0} \mathrm{C} \text { at } \\
\text { emergenc } \\
\text { e stage }\end{array}$ & $\begin{array}{c}\text { Duration } \\
\text { of } \\
\text { vegetativ } \\
\text { e stage } \\
\text { (days) }\end{array}$ & $\begin{array}{c}\text { Avg. Min. } \\
\text { Tem. }{ }^{0} \mathrm{C} \\
\text { at the } \\
\text { vegetativ } \\
\text { e stage }\end{array}$ & $\begin{array}{c}\text { Avg. } \\
\text { Max. } \\
\text { Tem. }{ }^{0} \mathrm{C} \\
\text { at the } \\
\text { vegetativ } \\
\text { e } \\
\text { stage }\end{array}$ & $\begin{array}{c}\text { Days } \\
\text { to } 1^{\text {st }} \\
\text { flower } \\
\text { initiation }\end{array}$ \\
\hline 10 November & 6 & 19.18 & 30.92 & 26 & 17.40 & 28.60 & 27 \\
20 November & 6 & 17.47 & 29.27 & 27 & 15.36 & 27.02 & 28 \\
30 November & 6 & 13.58 & 28.47 & 26 & 13.64 & 25.74 & 27 \\
10 December & 6 & 15.82 & 25.75 & 25 & 12.81 & 27.16 & 26 \\
20 December & 6 & 11.4 & 25.05 & 24 & 12.86 & 27.53 & 25 \\
30 December & 6 & 12.3 & 24.35 & 22 & 9.85 & 22.73 & 23 \\
\hline
\end{tabular}

Table 1b. Crop phenology and growth duration of Gardenpea (BARI motorshuti-3) as affected by sowing dates

\begin{tabular}{l|c|c|c|c|c|c}
\hline Sowing dates & $\begin{array}{c}\text { Grain } \\
\text { growth } \\
\text { duration } \\
\text { (days) }\end{array}$ & $\begin{array}{c}\text { Avg. Min. } \\
\text { Tem. }{ }^{0} \mathrm{C} \\
\text { in grain } \\
\text { growth } \\
\text { stage }\end{array}$ & $\begin{array}{c}\text { Avg. Max. } \\
\text { Tem. }{ }^{0} \mathrm{C} \\
\text { in grain } \\
\text { growth } \\
\text { stage }\end{array}$ & $\begin{array}{c}\text { Crop } \\
\text { growth } \\
\text { duration } \\
\text { (days) }\end{array}$ & $\begin{array}{c}\text { Avg. Min. } \\
\text { Tem. }{ }^{0} \mathrm{C} \text { in } \\
\text { total crop } \\
\text { growth } \\
\text { duration }\end{array}$ & $\begin{array}{c}\text { Avg. Max. } \\
\text { Tem. }{ }^{0} \mathrm{C} \text { in } \\
\text { total crop } \\
\text { growth } \\
\text { duration }\end{array}$ \\
\hline 10 November & 48 & 11.96 & 24.24 & 81 & 14.26 & 25.37 \\
20 November & 49 & 11.05 & 24.50 & 83 & 12.41 & 25.66 \\
30 November & 51 & 11.13 & 24.03 & 84 & 12.30 & 25.31 \\
10 December & 45 & 12.16 & 26.98 & 77 & 12.59 & 26.22 \\
20 December & 43 & 13.17 & 27.34 & 74 & 12.91 & 26.48 \\
30 December & 41 & 14.16 & 28.61 & 70 & 12.97 & 26.94 \\
\hline
\end{tabular}

Grain growth duration of 30 November, 20 November and 10 November sowings were longer due to low temperatures (Min. $11.05-11.13{ }^{\circ} \mathrm{C}$ and Max $24.03-24.24{ }^{\circ} \mathrm{C}$ ) prevailed at those time that might prolonged the grain growth period (48-51 days). On the contrary, 30 December and 20 December and 10 December sowings received high temperatures (Min. 12.16- $14.16^{\circ} \mathrm{C}$ and Max 26.98- $\left.28.61^{\circ}++\mathrm{C}\right)$ that shorten the grain growth period of BARI Motorshuti-3 (41-45 days). Similar results were observed by Gardner (1985), Savin and Nicolas (1996) who reported that high temperature reduced the length of reproductive period.

Leaf area index (LAI) varied at different sowing dates. LAI increased up to 40 DAE and thereafter decreased in all the sowing dates (Fig.1). Irrespective of sowing dates, maximum LAI was recorded in 30 November sowing followed by 20 November and 10 November sowings. Higher LAI indicates better leaf area expansion, which might helped in solar 
Ali et al.

radiation interception and efficient utilization of light for more dry matter production. The lowest LAI was recorded in 30 December followed by 20 December sowing.

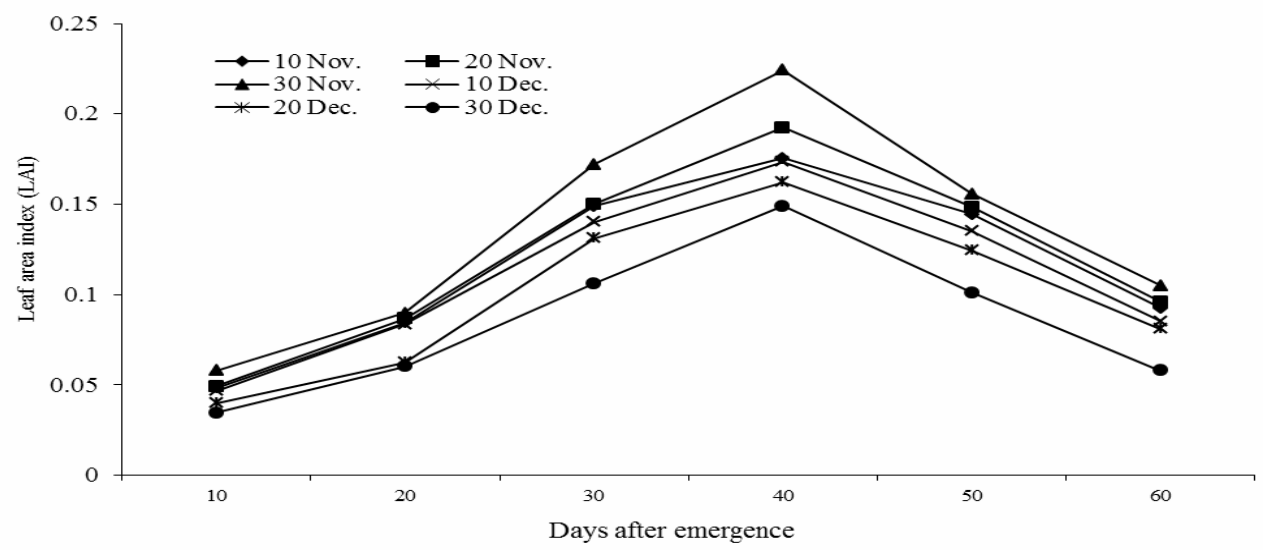

Fig. 1. Effect of sowing dates on leaf area index of BARI Motorshuti-3

Total dry matter (TDM) production increased gradually with the advancement of growth at different sowing dates (Fig. 2). TDM of 30 November sowing was higher which was more or less similar with 20 November and 10 November sowing. Low temperatures might favor the growth of early sowing (30 November, 20 November and 10 November) that caused higher TDM production. The lowest TDM was found in 30 December sowing followed by 20 December and 10 December sowings.

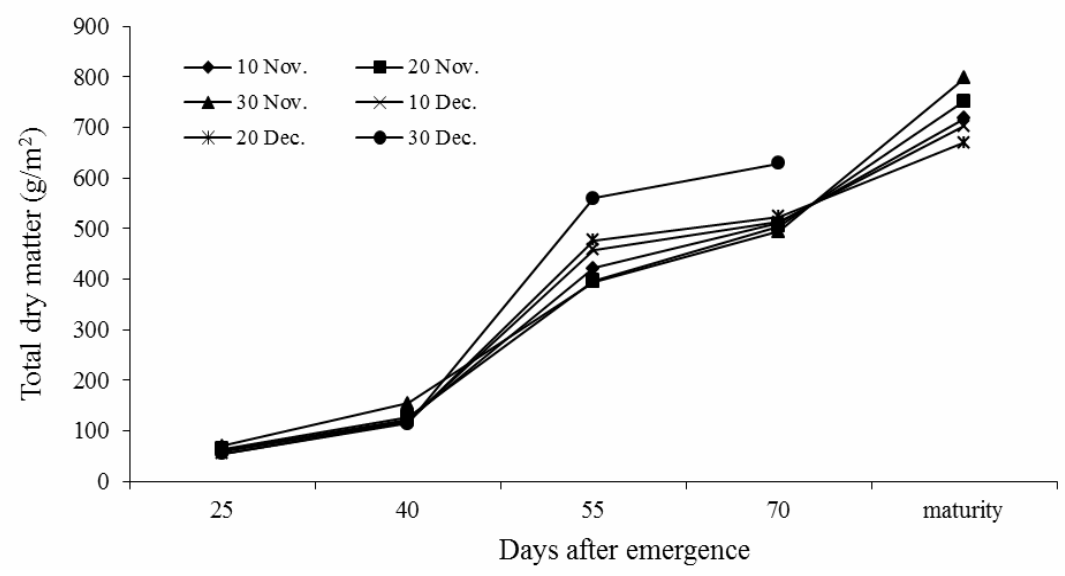

Fig. 2. Total dry matter of garden pea var. BARI Motorshuti-3 as influenced by different sowing dates

Crop growth rate increased up to $40-55$ days after emergence of crop then it decreased in all the sowing dates (Fig. 3). Higher CGR up to 40-55 DAE might be due to higher LAI. At the later stages of crop growth, declined in CGR caused by mutual shading and leaf senescence which might reduced the photosynthetic efficiency and ultimately reduced the dry matter accumulation rate. Similar findings were also observed with different crop species by Friend et al. (1962), Wall and Cartwright (1974), Stern and Kirby. (1979). 
Pea

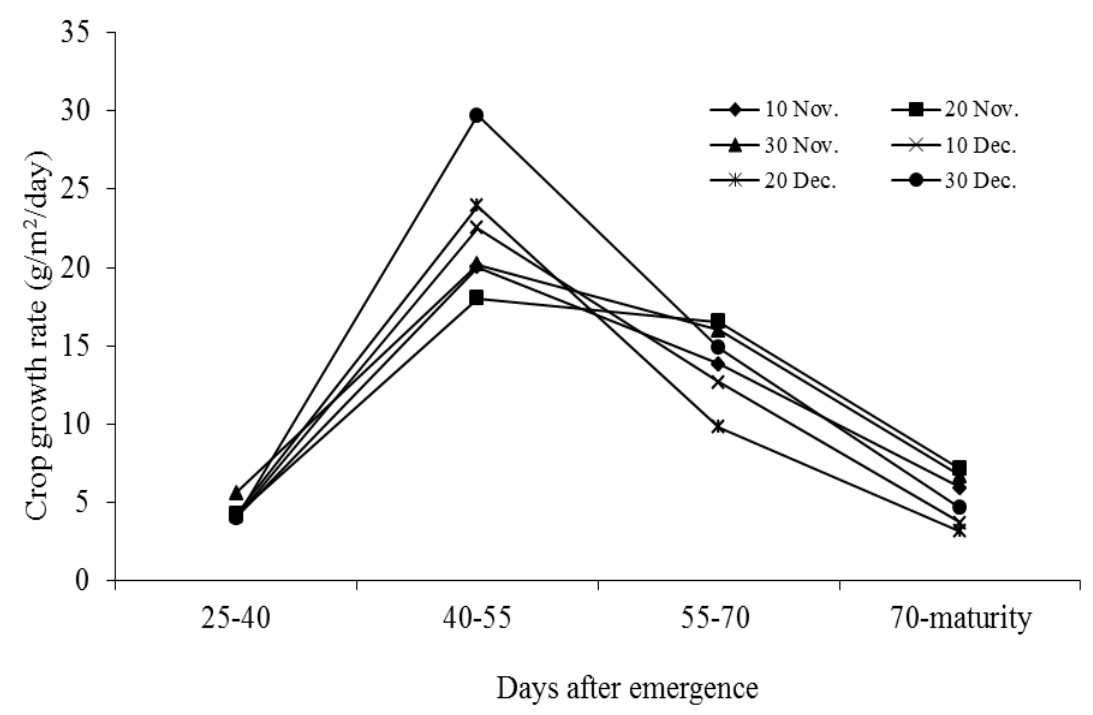

Fig. 3. Effect of sowing dates on the crop growth rate of Garden pea var. BARI Motorshuti-3

Significant differences were found in plant height, pods/plant, seeds/pod, 1000-seed weight and seed yield/ha due to variation of sowing dates at Joydebpur and Rangpur (Table 2a and 2b). Significantly the tallest plant $(56.63 \mathrm{~cm}$ at Joydebpur and $46.3 \mathrm{~cm}$ at Rangpur), maximum number of pods/plant (17.47 at Joydebpur and 15.7, Rangpur), seeds/pod (4.47 at Joydebpur and 6.0 at Rangpur) and highest 1000 -seed weights (255.19g at Joydebpur) were recorded in 30 November sowing. December 30 sowing gave the shortest plant $(36.53 \mathrm{~cm}$ at Joydebpur and $37.0 \mathrm{~cm}$ at Rangpur), minimum number of pods/plant (12.19 at Joydebpur and 9.3 at Rangpur), and seeds/pod (2.91 at Joydebpur and 4.0 at Rangpur) and lowest 1000 -seed weight (203.07g at Joydebpur).

Table 2a. Effect of sowing dates on yield components and seed yield of BARI motorshuti-3 at BARI, Joydebpur, Gazipur

\begin{tabular}{l|c|c|c|c|c}
\hline Sowing dates & $\begin{array}{c}\text { Plant } \\
\text { height } \\
\text { (cm) }\end{array}$ & $\begin{array}{c}\text { Pods/plant } \\
\text { (no.) }\end{array}$ & $\begin{array}{c}\text { Seeds/pod } \\
\text { (no.) }\end{array}$ & $\begin{array}{c}\text { 1000-seeds/ } \\
\text { weight }(\mathrm{g})\end{array}$ & $\begin{array}{c}\text { Seed yield } \\
\text { (t/ha) }\end{array}$ \\
\hline 10 November & 51.97 & 13.67 & 4.21 & 222.14 & 2.90 \\
20 November & 50.63 & 15.89 & 4.21 & 245.16 & 3.56 \\
30 November & 56.63 & 17.47 & 4.47 & 255.19 & 3.66 \\
10 December & 42.63 & 13.01 & 3.01 & 220.22 & 2.36 \\
20 December & 37.33 & 12.44 & 3.71 & 215.66 & 2.27 \\
30 December & 36.53 & 12.19 & 2.91 & 203.07 & 1.19 \\
\hline $\mathrm{LSD}_{(0.05)}$ & 5.053 & 0.91 & 0.57 & 10.77 & 0.38
\end{tabular}


Ali et al.

\begin{tabular}{l|cc|c|c} 
CV (\%) & 6.04 & 3.55 & 8.32 & \multicolumn{2}{c}{2.61} & 7.78 \\
\hline $\begin{array}{l}\text { Table 2b. Effect of sowing dates on yield components and seed yield of BARI Motorshuti-3 } \\
\text { at ARS, Burirhat, Rangpur }\end{array}$ \\
$\begin{array}{l}\text { Sowing dates } \\
\text { 10 November }\end{array}$ & $\begin{array}{l}\text { Plant height (cm) } \\
\text { 20 November }\end{array}$ & Pods/plant (no.) & $\begin{array}{c}\text { Seeds/pod } \\
\text { (no.) }\end{array}$ & Seed yield (t/ha) \\
30 November & 42.0 & 13.3 & 4.7 & 1.98 \\
10 December & 46.0 & 15.7 & 6.0 & 2.43 \\
20 December & 45.7 & 15.7 & 5.3 & 2.36 \\
30 December & 39.7 & 14.0 & 4.7 & 2.03 \\
\hline LSD & 11.0 & 4.3 & 1.68 \\
CV (\%) & 37.0 & 9.3 & 4.0 & 1.58 \\
\hline
\end{tabular}

November 30 sowing received lower day/night temperature that causes longer crop growth duration specially the grain growth period and ultimately more TDM production and translocation of TDM to pods/plant, seeds/pod and 1000-seed weight. On the other hand, 30 December sowing received higher day/night temperature that hastens forced maturity and reduced TDM production and translocation to the yield components. Similar results were recorded by Peterson and Loomis (1949) in Kentucky bluegrass, Gardner and Loomis (1953) in orchard grass, Lindsey and Peterson (1964) in Poa pratensis L.

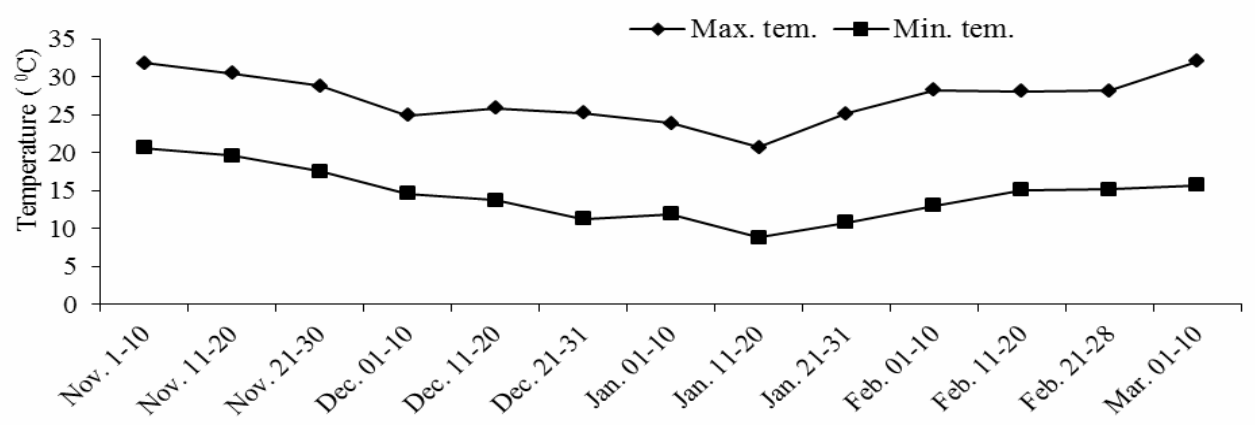

Fig.4. Maximum and minimum temperature during garden pea (BARI Motorshuti-3) growing period (2011-2012) at BARI, Joydebpur, Gazipur.

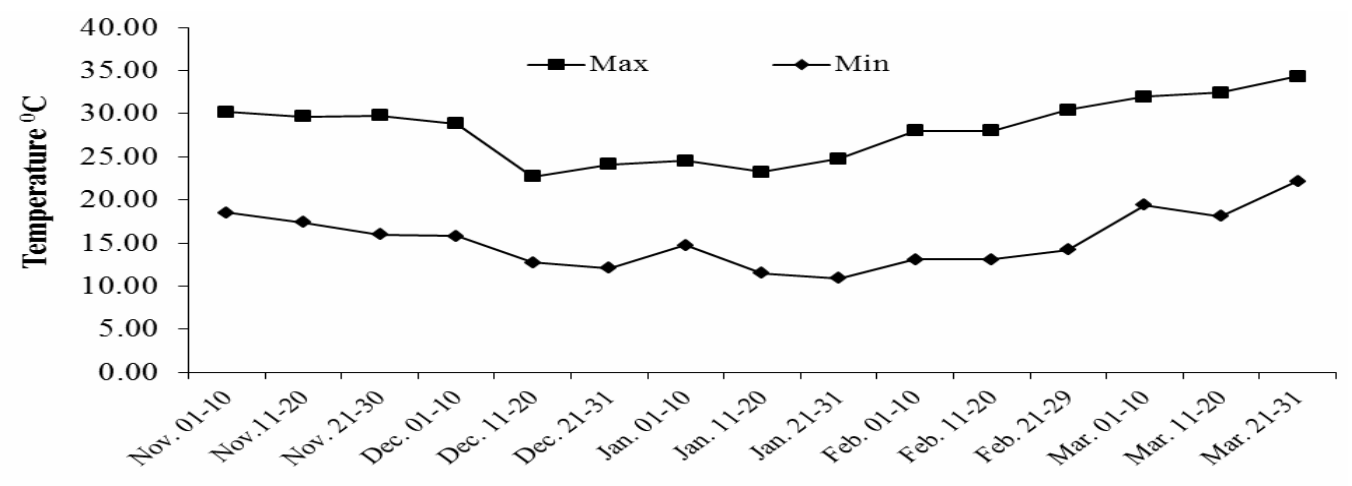


Effect of Sowing Time Based Temperature Variations on Growth, Yield and Seed Quality of Garden

Pea

Fig. 4. Maximum and minimum temperature during gardenpea (BARI Motorshuti-3) growing period (2011-2012) at ARS, Burirhat, Rangpur.

Seed yield is the function of pods/plant, seeds/pod and 1000-seed weight. Date of sowing significantly influenced the seed yield/ha of garden pea. November 30 sowing produced the highest seed yield (3.66 t/ha at Joydebpur and $2.43 \mathrm{t} / \mathrm{ha}$ at Rangpur) which was statistically similar with 20 November sowing at both the location. The lowest seed yield (1.19 t/ha at Joydebpur and $1.58 \mathrm{t} / \mathrm{ha}$ at Rangpur) was obtained in 30 December sowing and it was identical with 20 December sowing at the both location Joydebpur and Rangpur. The highest seed yield at 30 November might be due to maximum number of pods/plant and seeds/pod and highest 1000-seeds weight. This study indicated that raise in temperature reduced the grain growth duration resulted in yield reduction, which is in agreement with the findings of Mohanty et al. (2001), Bosswell (1926), Kruger (1973) and Silim et al. (1985).

Seed quality character also affected significantly due to different dates of sowing. At Joydebpur, significantly the lowest moisture content $(12.10 \%)$, higher germination percentage (97\%), maximum vigor index (2.52) and highest protein content $(26.51 \%)$ was recorded in 30 November sowing. The highest moisture content (12.64\%), lower germination percentage (91.33\%), minimum vigor index (1.65) and lowest protein content $(25.70 \%)$ was recorded in 10 December sowing (Table 3).

Table 3. Effect of sowing dates on seed quality characters of BARI Motorshuti-3

\begin{tabular}{l|c|c|c|c|c}
\hline Sowing dates & $\begin{array}{c}\text { Moisture } \\
\text { content } \\
(\%)\end{array}$ & $\begin{array}{c}\text { Germination } \\
(\%)\end{array}$ & $\begin{array}{c}\text { Average } \\
\text { seedling dry } \\
\text { weight }(\mathrm{g})\end{array}$ & Vigor index & $\begin{array}{c}\text { Protein } \\
\text { content } \\
(\%)\end{array}$ \\
\hline 10 November & 12.43 & 93.33 & 0.019 & 1.79 & 25.85 \\
20 November & 12.38 & 95.00 & 0.023 & 2.19 & 26.24 \\
30 November & 12.10 & 97.00 & 0.026 & 2.52 & 26.51 \\
10 December & 12.49 & 93.67 & 0.018 & 1.69 & 25.08 \\
20 December & 12.59 & 92.33 & 0.018 & 1.66 & 24.21 \\
30 December & 12.64 & 91.33 & 0.018 & 1.64 & 22.70 \\
\hline LSD $(0.05)$ & 0.02 & 3.28 & 0.002 & 0.25 & 0.41 \\
CV (\%) & 0.12 & 1.92 & 6.60 & 7.28 & 0.90 \\
\hline
\end{tabular}

\section{Conclusion}

From this study it might be concluded that November 20-30 would be optimum time of sowing for maximum seed yield and quality seed of garden pea.

\section{References}

Abdul-Baki, A. A. and J. D. Anderson. 1973. Vigor determination in soybean seed by multiple criteria. J. Crop. Sci. 13: 630-633.

Boswell, V. R. 1926. The influence of temperature upon the growth and yield of garden peas. Proceedings of the American Soc. Hort. Sci. 23: 162-168.

Boyer, J. S. 1982. Plant productivity and environmental, Science 218: 443-448. 
Ali et al.

Friend, D. J. C., V. A. Helson and J. E. Fisher. 1962. Leaf growth in marquis wheat, as regulated by temperature, light intensity and day length. Can. J. Bot. 40: 1299-1310.

Gardner, F. P. and W. E. Loomis. 1953. Floral induction and development in orchard grass. Plant Physiol. 28: 201-217.

Gardner, F. P., R. B. Pearce and R. L. Mithchel. 1985. Physiology of field crops. The IOWA state Univ. Press, IOWA. 50010: 156-186.

ISTA. 1999. International rules for seed testing. Seed Science and Technology. International Seed Testing Association, Zurich, Switzerland. 27:155-199.

Kruger, S. N. 1973. Effect of time of planting on the seasonal yield of Pisum sativum L. Qld. J. Agric. Anim. Sci. 30: 25-38.

Lindsey, K. E. and M. L. Peterson. 1964. Floral induction and development in Poa pratensis L. Crop. Sci. 4: 540-544.

Mohanty, S. K., B. Baisakih., U. K. Dikshit and B. Bhol. 2001. Kalamung, a promising local mungbean cultivar. Environ. Ecol. 16(1): 222-223.

Pandey, B. P., S. K. Sirvastava and R. S. Lal. 1981. Genotype and environment interaction in lentil. LENS. 8: 14-17.

Peterson, M. L. and W. E. Loomis. 1949. Effect of photoperiod and temperature on growth flowering of Kentucky bluegrass. Plant Physiol. 24: 31-43.

Savin, R. and M. E. Nicolas. 1996. Effect of short periods of drought and high temperature on grain growth and starch accumulation of two malting barley cultivars. Aust. J. Plant Physiol. 23: 201-210.

Silim, S. N., P. D. Hebblethwaite and M. C. Heath. 1985. Comparison of the effects of autum and spring sowing date on growth and yield of combining peas (Pisum sativum L). J. Agric. Sci. 104: 35-46.

Sing, B. D. 2006. Breeding for resistance to temperature stress. Plant Breeding principle and methods. New Delhi, India. 7: 510-511.

Sousa-Majer. M. J., Turner. N. C., D. C. Hardle., L. R. Morton., L. Morton and J. V. Thomas. 2004. Response to water deficit and high temperature of transgenic peas (Pisum sativum L.). J. Exp. Bot. 55(396): 497-505.

Stern, W. R. and E. J. M. Kirby. 1979. Primordium initiation at the shoot apex in four contrasting varieties of spring wheat in response to sowing date. J. Agric. Sci. 93: 203-215.

Wall, P. C. and P. M. Cartwright. 1974. Effects of Photoperiod, temperature and vernalization on the phenology and spikelet numbers of spring wheats. Ann. Appl. Biol. 76: 299-309. 